\author{
Adam Jakub Jarych \\ https://doi.org/10.26485/AAL/2019/65/2
}

\title{
RELIGIOUS LIFE SURROUNDING THREE THERMAL SPRINGS IN ANCIENT DACIA ${ }^{1}$
}

\begin{abstract}
The paper deals with the three most important thermal springs in ancient Dacia, on which part of the religious life of the province centred. The available source material makes it possible to determine which deities received the most worship among the visitors enjoying the pleasures of Ad Mediam, Ad Aquas, and Germisara. The collected sources also let us find out what groups of the province's inhabitants were treated in those extremely popular centres, referred to by many researchers as ancient spa resorts.
\end{abstract}

Keywords: Dacia, hot springs, religion, cult

ABSTRAKT Niniejszy artykuł został poświęcony trzem najważniejszym źródłom termalnym w antycznej Dacji, w obrębie, których kształtowała się część życia religijnego prowincji. Dostępny materiał źródłowy pozwala prześledzić, jakie bóstwa cieszyły się największą czcią wśród kuracjuszy korzystających z uroków ośrodków w Ad Mediam, Ad Aquas czy Germisara. Zebrane przekazy pozwalają także na prześledzenie jakie grupy obywateli leczyły się w tych popularnych miejscach, określanych przez wielu naukowców mianem antycznych „spa”.

Słowa kluczowe: Dacja, gorące źródła, religia, kult

Dacia was always known for its rich natural resources, i.e., gold and silver. ${ }^{2}$ However, metals were not the only material for which the region was famous. This Danube province also had thermal waters, which were very popular (and remain so today). The hot springs at Ad Mediam (Băile Herculane), Ad Aquas (Călan), and Germisara (Geoagiu-Băi) ${ }^{3}$ were visited in antiquity by patients from all over the province. In addition to hygienic and medical ${ }^{4}$ properties, these centres constituted an important space for religious cults, and it is with those that this paper deals. ${ }^{5}$

The great popularity of the springs is confirmed by the fact they were placed on the Tabula Peutingeriana, a late-Empire road map. The springs at Ad Mediam and Germisara were marked by text

1 Article is the effect of realization of the research project no. 2016/21/B/HS3/02923 financed by National Science Centre, Poland. Translated by M. Jarczyk.

2 Żmudziński 2006: 679. Alongside gold and silver, Dacia exported salt, hides, and wood.

3 Fodorean, 2012: 211-222; Fodorean 2019: 219.

4 Gui 2011: 117.

5 Oltean 2007: 99; Rosca, Bendea, Vijdea 2016: 98; Szabó 2018: 146. entries by the cartographers who made the map, while the centre at Ad Aquas came with a special drawing (a vignette) of a building housing the spa or the thermal waters themselves. According to Florin Fodorean, there is nothing unusual about the baths at Ad Mediam and Germisara receiving only text entries, as the map had its limitations, if only due to the size of the piece of parchment, so the choice of locations to include was constrained by the scale the authors of the map adopted, and somewhat arbitrary. $^{6}$

Another indication of how popular they were is the considerable number of votive inscriptions discovered there, ${ }^{7}$ which make it possible to delineate the most significant cults worshipped at the springs, as well as revealing a cross-section of the baths' visitors. Combined with small finds such as coins, the available epigraphic material also allows us to draw certain conclusions regarding the chronology of the development and prosperity of the springs at Ad Mediam, Ad Aquas, and Germisara.

6 Fodorean 2012: 213.

7 Boda, Timoc, Bunoiu 2017: 173-185. 
The hot springs

at Ad Mediam (Băile Herculane)

The hot springs at Ad Mediam were rediscovered in the 18th century by the governor of the Banat, Johann Andreas von Hamilton, who had the artefacts (that is, inscriptions and statues of Hercules) transported out. They were heading for Vienna, but some sank near Budapest and never arrived. ${ }^{8}$ It is to those finds that the town owns its modern name of Băile Herculane, or Herkulesbad. It should be noted, however, that von Hamilton was not an archaeologist, and his methods were quite controversial. His main objective was to pull down the old structures to clear space for a new resort that would serve the Habsburg dynasty, so the Roman-era material was never properly conserved or catalogued, with a large part of the architecture being simply destroyed. ${ }^{9}$

The material from Ad Mediam was first catalogued by Pascal Caryophyllus, active in the 18 th century. The chronicler noted a sanctuary to Hercules which was built next to one of the hot springs and its accompanying caves, near the river Cerna on the northern outskirts of the modern town. On the remains of the walls of one of the structures, which had stood near the Hotel Roman built under Nicolae Ceaușescu, there was also a sculpted relief of the hero wielding his club; a copy of the relief is exhibited in the lobby of the hotel. Other objects found within the precinct included the above-mentioned statues, approximately one metre tall and made of marble. Meanwhile, on the right bank of the river, near to a military sanatorium, two sculptures were discovered of women lying down, identified as nymphs, which had decorated a fountain: Ad Mediam must have also had a nymphaeum, attested to by epigraphical sources. The Roman-era material also includes sarcophagi, tombstones, numerous roof tiles bearing the stamps of military units stationed in Dacia (the legions VII Claudia, XIII Gemina, and IV Flavia Felix), and of course inscriptions, which constitute the major source for our better understanding the religious life of the province. ${ }^{10}$

The epigraphic material most often points to the worship of Hercules, who was seen as a guardian

8 Boda, Timoc, Bunoiu 2017: 174

9 Szabó 2018:146.

10 Benea, Lalescu 1998: 267-301; Bozu, Miceli 2005: 130-131; Boda, Timoc, Bunoiu 2017: 180. Some information on what the town looked like in the 18th century is provided by a 1774 map of the resort, now kept at the state archives at Caransebeș. of the hot springs. Of the twelve inscriptions, three were dedicated to the hero bearing the epithet of Invictus; two of Sanctus Augustus and of Salutifer, one each. The other five contain no cult epithet, and one of the inscriptions is a joint dedication to Hercules, Venus, and Mercury. ${ }^{11}$ According to the 19th-century writings of Nicolae Stoica de Haţeg, Aesculapius and Hygieia were also worshipped at the same site, which epigraphical sources do mention. ${ }^{12}$ Characteristically, Aesculapius was also among the major patron deities of military baths throughout the province. ${ }^{13}$ The remaining five inscriptions found at Ad Mediam were dedicated to Jupiter, the Genius Loci, and deities of the springs (Dii et Numini Aquarum),${ }^{14}$ but other gods were worshipped there as well. Another find from the resort is a bronze tablet $(10.5 \times 12 \mathrm{~cm}$ in size $)$ dedicated to Sucellus and his companion Nantosuelta. ${ }^{15}$ Depicting Celtic deities (standing for plentiful harvest on the one hand, and death on the other), the artefact is a significant example of official cults being permeated by their local variants, brought to Dacia by patients visiting the province for medical reasons.

The preserved material contains references to over thirty people, two of whom were women, while four were slaves who offered vota in their masters' names. ${ }^{16}$ One of the women was a Septimia Valentina, her name preserved on a tombstone; another inscription lists a Iunia Cyrilla:

Aesculap(io)| |et Hygiae|pro salute
Iuniae $\mid$ Cyrillae quod a|longa infirmita|te virtute
aqua|rum
numinis sui|revocaverunt $\mid$ T(itus?) B(---?) A(---?)
eius v(otum)
s(olvit) l(ibens) $m(\text { erito })^{17}$

11 CIL III, 1565 = IDR III/1, 59; CIL III, $1564=$ IDR III/1, 57; CIL III, 1565 = IDR III/1, 58; CIL III, $01566=$ IDR III/1, 67; CIL III, $1567=$ IDR III/1, 68; CIL III, $1568=$ IDR III/1, 60; CIL III, $1569=$ IDR III/1, 61; CIL III, $1570=$ IDR III/1, 62; CIL III, $1571=$ IDR III/1, 63; CIL III, 1572 = IDR III/1, 64; CIL III, $1573=$ IDR III/1, 66; CIL III, 1573a = IDR III/1, 65.

12 CIL III, $1560=$ IDR III/1, 54; CIL III, $1561=$ IDR III/1, 55.

13 Varga 2018: 78. The god's cult was attested to in the military baths at Arcobadara, among other places.

14 CIL III, 1574 = IDR III/1, 79; CIL III, $1562=$ IDR III/1, 56; CIL III, $01566=$ IDR III/1, 67.

15 Nemeti 2001: 162.

16 Boda, Timoc, Bunoiu 2017: 175.

17 CIL III, $1561=$ IDR III/1, 55. 
Scholars believe the inscription, placed on a marble altar ( $73 \times 37 \times 30 \mathrm{~cm}$ in size $)$, was probably carved at the behest of the woman's husband Titus (?). In the text, he thanks Aesculapius and Hygieia for curing his wife, healed by the properties of the springs at Ad Mediam, from a long illness. As suggested by Casaba Szabó, the peculiar form of the dedication testifies to a personal religious experience, serving to preserve the memory of a given sacred space. ${ }^{18}$ Sadly, at present it is impossible to determine where the funder was from or who he was. Some researchers suggest he was a patrician who came to Dacia from provinces south of the Danube, perhaps Moesia Superior or Inferior, but that is pure speculation. ${ }^{19}$

It is much less of a problem to determine the origins of other patrons of Ad Mediam; for example, we have the joint dedication by Ulpius Secundinus, Marius Valens, Pomponius Haemus, Iulius Carus, and Valerius Valens, who funded a marble altar (92 x 48 x 44 cm) Dis et Numinibus Aquarum:

Dis et Numinib(us)/Aquarum/Ulp(ius) Secundinus/ Marius Valens/Pomponius Haemus/Iul(ius) Carus Val(erius) Valens/legati Romam ad/consulatum Seve/riani c(larissimi) v(iri) missi incolu/mes reversi ex voto E.A. ${ }^{20}$

The monument was erected in $153 \mathrm{CE}$ by officials from Ulpia Traiana Sarmizegetusa after their safe return to Dacia from Rome, where they had been on the occasion of Marcus Sedatius Severianus coming into consulship. ${ }^{21}$

Besides officials, members of the army made up another considerable group of patrons. Among them were a Marcus Aurelius, a prefect of Legio XIII Gemina, a Titus Aurelius Geminanus, a veteran of the same legion, and a Lucius Pompeius Celer, a prefect of the Cohors I Ubiorum in Ad Mediam, all three leaving dedications to Hercules and Aesculapius ${ }^{22}$. The examples listed above all point to the degree to which religion permeated all aspects of life in the province, thus emphasizing the divine character and the specific nature of the location. ${ }^{23}$

18 Fodorean 2012: 217; Szabó 2018: 148.

19 Boda, Timoc, Bunoiu 2017: 175.

20 CIL III, $1562=$ IDR III/1, 56.

21 Fodorean 2012: 218.

22 CIL III, $1560=$ IDR III/1, 54; CIL III, $1569=$ IDR III/1, 61; CIL III, 1571 = IDR III/1, 63.

23 Byros 2011: 1-3.
The thermal springs

at Germisara (Geoagiu-Băi)

The virtues of the hot springs at Germisara were probably already known before the Roman invasion, as indicated by the Thracian-Getic toponym (meaning hot and salty, sc. waters), as well as the many numismatic finds from places such as Thasos and Dyrrachium, or the Republican denarii found sunk in one of the springs. ${ }^{24}$ The resort lay in the valley of the Geoagiu, on the right bank of the river Mureş, five kilometres from an auxiliary camp; the unit stationed there was Numerus Singulariorum Britannicorum. In addition, two settlements developed in the valley, one civilian and the other military. In ancient literary accounts, the whole region was referred to as Germisara. ${ }^{25}$

Although the ancient complex was already known in Renaissance times, archaeological work only began in $1986 .{ }^{26}$ The extant material mentions thirty-one persons; fourteen of whom made dedications to the nymphs of the hot springs, often giving the cult epithets of Augustis, Sancta, or Salutifera. Other cults attested in the spa include those of Jupiter, Aesculapius and Hygieia, Hercules, Fortuna, Pater Liber, and Diana, whose statue was found in a grotto containing a hot spring. ${ }^{27}$ The statue, $67 \mathrm{~cm}$ high, shows the goddess clad in a chiton; she may have held captured quarry in her left hand, while her right arm bends towards the quiver on her back. A dog walks on her left. According to Ioan Piso and Adrianna Rusu, the sculpture was made in one of the local Dacian workshops. $^{28}$

During the Roman period, the complex was regularly expanded. Alongside natural hollows with springs in them, it included a nymphaeum as well as many buildings about whose function researchers are not certain. Some of the structures were probably used for religious practices, among them the structure CR1, which has been identified as a fanum..$^{29}$ One of the most interesting artefacts

24 Piso, Rusu 1990: 9.

25 Fodorean 2012: 214.

26 Pescaru, Pescaru 2011: 439-452; Szabó 2018: 148-149. In spite of the Thracian-Dacian toponym and the presence of a settlement on a hill near the springs, researchers have not yet encountered any material to unambiguously confirm the springs were used by the Dacians.

27 IDR III/3, 231-247; Boda, Timoc, Bunoiu 2017:

178; Szabó 2018: 148-149.

28 Piso, Rusu 1990: 9.

29 Pescaru, Pescaru 2011: 439-452. 


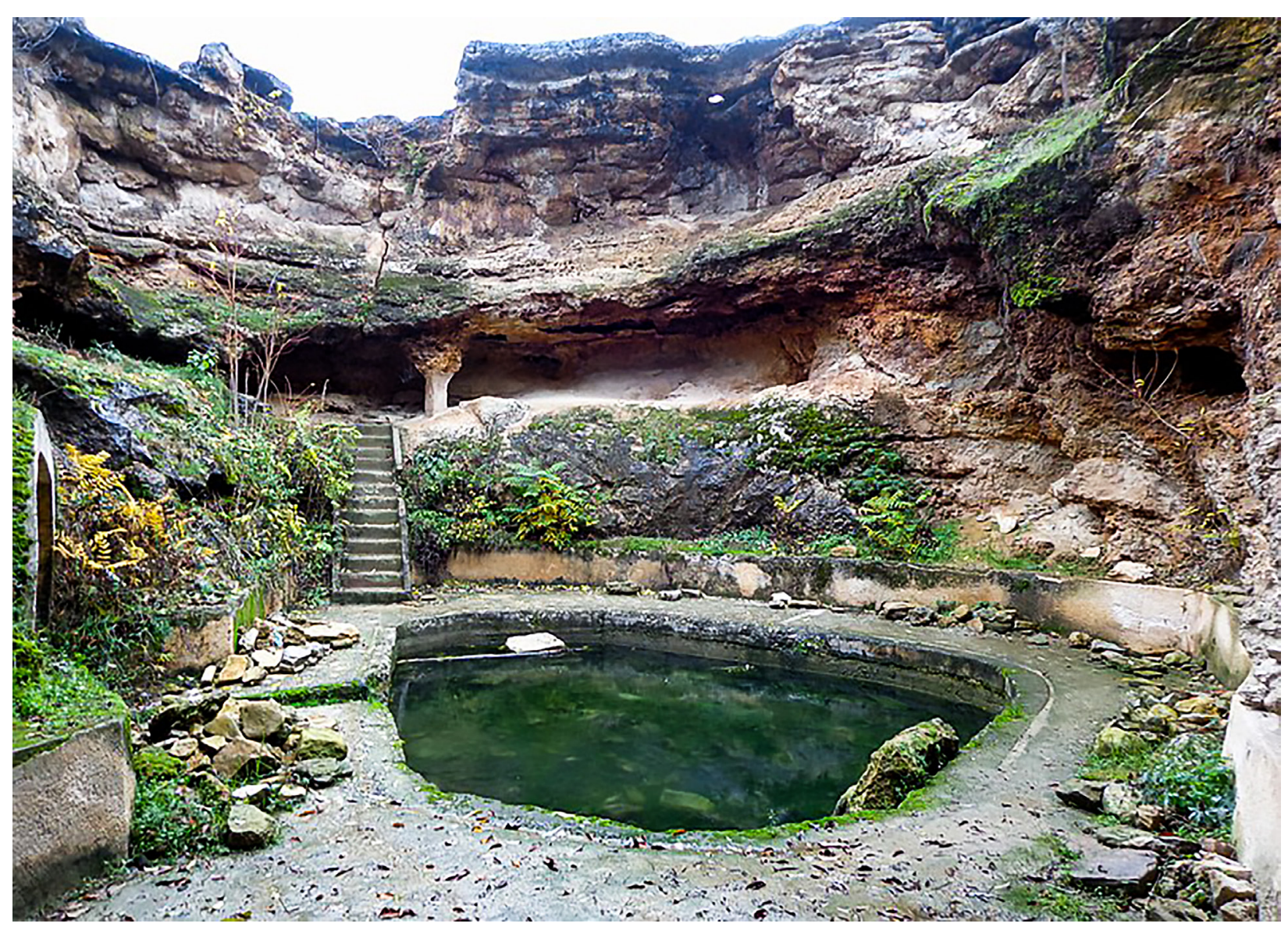

Germisara hot springs (wikimedia)

dedicated to the nymphs is a golden lamella found in a cistern:

\section{Nymf/is(!) Dece/balus Lu/ci posuit ${ }^{30}$}

It can be supposed that this Decebalus son of Lucius was a freedman; his identity is difficult to determine, but researchers consider it possible he was Dacian. If so, then the object in question is one of the few finds which could confirm the process of acculturation as it effected religious identity of Romanized sacred spaces. ${ }^{31}$ The inscription on the gold lamella is not the only one dedicated to the nymphs; on one of the tablets, a text remains, placed there by one Bassus, most likely also a freedman, who thanked a nymph for restoring him to health. Its exceptional feature is that the funder only mentions one of the patron goddesses of the springs, calling her regina undarum Nympha. ${ }^{32}$

30 ILD 325. In total, eight golden lamellae were discovered.

31 Szabó 2018: 148-149.

32 CIL III, $0139=$ IDR III/3, 239.
Obviously freedmen and their sons were not the only people who made dedications to the nymphs. For example, votive inscriptions are atwere placed on stelae and altars by army officers and provincial governors. Among the former there is a bilingual hymn to the goddesses of the springs carved on a limestone stele $(160 \times 60 \times 15 \mathrm{~cm})$ at the behest of a centurion of Legio V Macedonica, one Sentius Iustinus. Even though the monument was discovered over thirty years ago, it has not been thoroughly edited yet. The stele itself is incomplete, with three pieces remaining. The text, only partly preserved, is written in hexameters:

Sunt Getici fontes diuina nympha creati, cui formonsus ager uicinus Germisarae est, cui miles Brittannicus sollemnia annua ducit ex uoto efferens soluitque uota priora temporis excessi et rusum suscipit ipse, cui cristatus apex procumbit uortice summo. Hinc undas miles? conuenas uidere solens, unde et pu[--- ae?]quor inde salutis excipiunt [---] uirtus [---] [---] [---]que uouerat portam 


\section{[---] praepositus hunc tibi [---] \\ [---]re cingeris uite comati}

[---]o nata dono circumdata uuis; te precor Odrysta donum terrena? recondas.

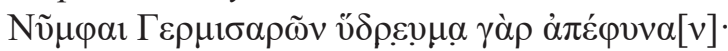

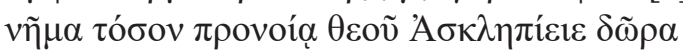

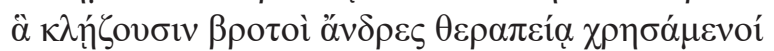

$$
\pi \varepsilon[\rho]
$$

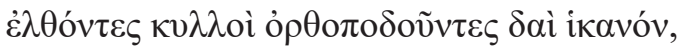

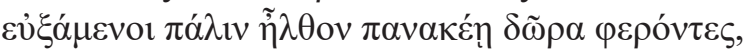

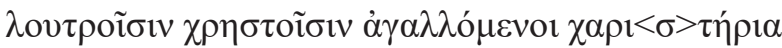

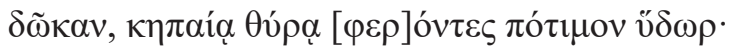

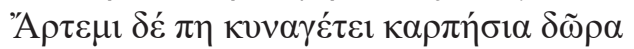

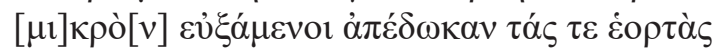

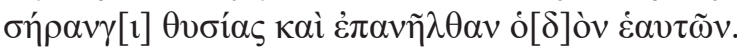

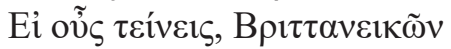

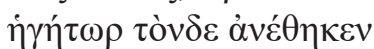

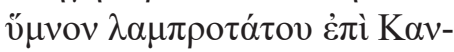

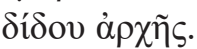

C(aius) Sentius Iustinus, (centurio) l(e)g(ionis)

$V$ Mac(edonicae), agens per terr(itorium) Lucanum $^{33}$

The inscription is extremely interesting, as the centurion mentions in it a nymph he calls Odrysta. Piso, who analyzed the monument, believes that she was a patron goddess of woods and springs, and that her name derived from a Dacian word for oak. ${ }^{34}$ Other deities are mentioned, such as Aesculapius, Hypnus and Artemis, and the text lists the treatments Iustinus underwent during his stay at the resort, where in addition to hot baths, sleep was practised as a form of treatment. This method was very popular in Aesculapius' sanctuaries. As Szabó suggested, the inscription is exceptional testimony to local religious experience, the memory of which was preserved in the form of a stone stele. ${ }^{35}$

The second group of dedications comprises those altars erected by provincial governors, who came to the spa from Apulum. In addition to expressing the worship of deities (the nymphs or Fortuna), they are dedicated to the prosperity of emperors or members of their immediate families. Let me illustrate this category with an inscription erected by one Marcus Statius Priscus:

Nymphis Aug(ustis) pro salute

Imp(eratoris) Caes(aris) Titi

Ael(i) Hadr(iani) Antonini Aug(usti) Pii p(atris)

33 Piso 2015: 47-68.

34 Piso 2015: 47-68.

35 Szabó 2018: 153.

\author{
p(atriae) \\ M(arcus) Statius Priscus leg(atus) Aug(usti) p[r(o) \\ pr(aetore)] \\ $v$ (otum) s(olvit) l(ibens) $m{\text { (erito })^{36}}^{36}$
}

Another altar $(100 \times 52 \times 46 \mathrm{~cm})$ was erected at the command of a Lucius Octavius Iulianus for the good fortune of Lucius Septimius Severus and his two sons: ${ }^{37}$

\section{Fortuna[e]/pro salutelaug(ustorum) n(ostrorum) (trium]/L(ucius) Octavius I[u]/lianus co(n)s(ula- ris) II[I]/Dac(iarum) fieri iussit/instante ... $L \mathrm{Ge}-$ \\ (?)/M A N T [p]rae[f(ecto) a]lae/Astu[rum $]^{38}$}

As can be seen, dedications by the governors of the province are much more official in tone than those of other visitors. In addition to the worship of deities, the officials stressed their respect for the reigning dynasty, to which they owed their political career in the province.

\section{Ad Aquas (Călan)}

Unfortunately, the epigraphic sources for the thermal springs at Ad Aquas are the most meagre. Even though the resort lay on the main route from Ulpia Traiana Sarmizegetusa to Apulum, only nine votive inscriptions have been discovered in its vicinity. They are not as original as either Iustinus' stele or Cyrilla's monument, but the texts engraved on them include dedications to Jupiter, Jupiter Dolichenus, Hercules, Fortuna and Silvanus. ${ }^{39}$

As in the two previous cases, the Ad Aquas resort, of which one huge pool remains to this day, $94 \mathrm{~m}$ in diameter, was patronized by officials and veterans from all over the province. One of them was a Valerius Ingenuus, a veteran of Legio XIII Gemina stationed in Apulum; besides a dedication to Jupiter Dolichenus, he made a votive offering for the good fortune of emperor Caracalla. ${ }^{40} \mathrm{As}$ for officials visiting Ad Aquas, an inscription remains dedicated by one Quintus Decius Vindex to Fortuna and the decurions of Ulpia Traiana Sarmizegetusa. ${ }^{41}$

36 CIL III, $940=$ IDR III/3, 241.

37 Fodorean 2012: 215.

38 IDR III/3, 233.

39 IDR III/3, 6-11; Fodorean 2012: 216; Boda, Timoc, Bunoiu 2017: 178.

40 IDR III/3, 15.

41 IDR III/3, 10; IDR III/3, 17-19. 


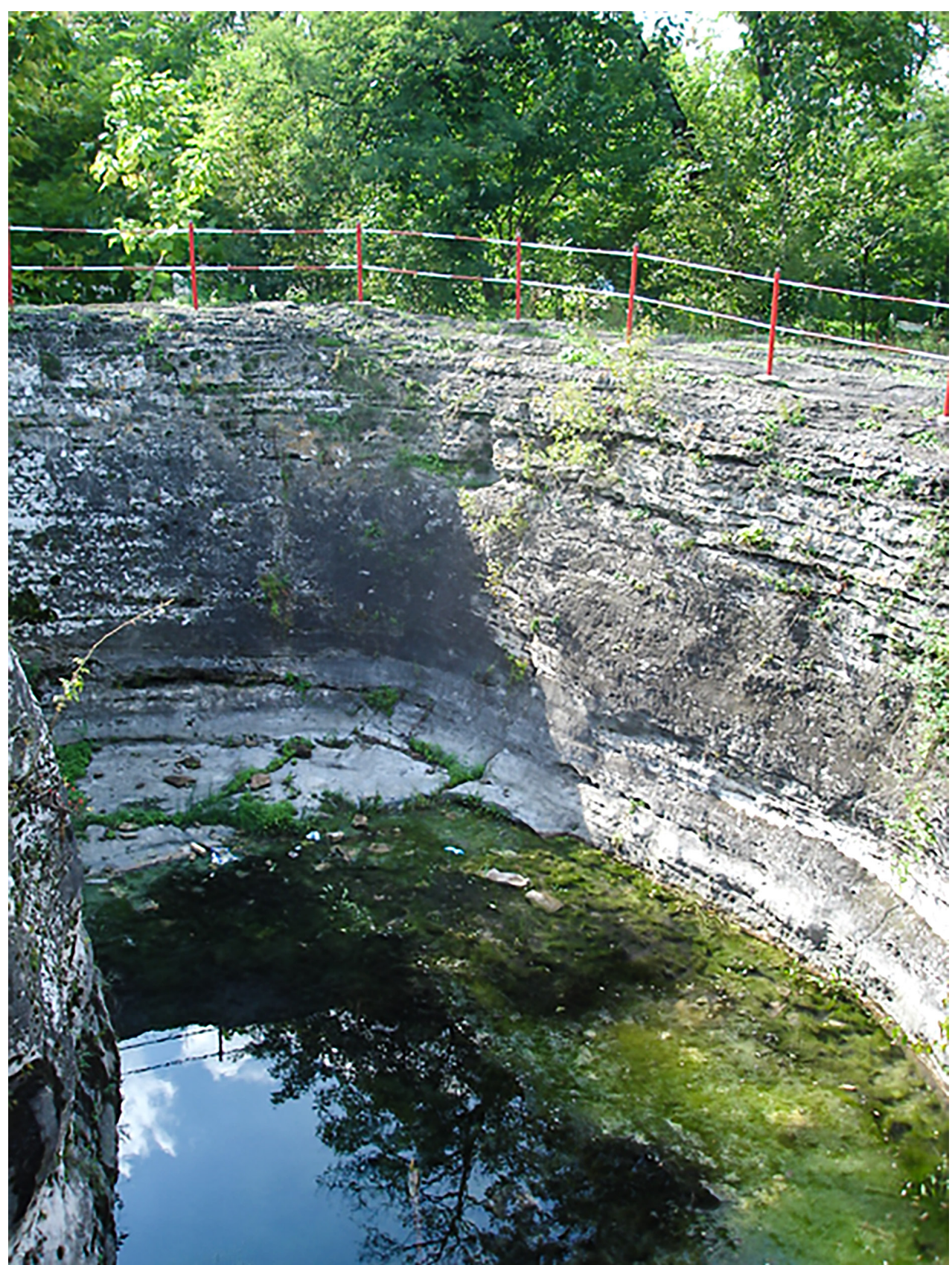

Ad Aquas hot springs (wikimedia)

Ismola Boda, Călin Timoc, and Victor Bunoiu were right to observe that in the case of the baths at Ad Aquas it is impossible to distinguish any clear preference as to the gods worshipped there. Graeco-Roman deities were favoured as in the other two resorts, perhaps because the spa was mostly used by magistrates from Ulpia Traiana Sarmizegetusa, who expressed their religious feelings through the official pantheon due to the offices they held. ${ }^{42}$

42 Boda, Timoc, Bunoiu 2017: 181.
To sum up the collected material from the three thermal resorts in Dacia, clearly most of the dedications were official votive offerings. Only a few are personal, such as that in which Titus (?) thanks the deities for healing his wife, or as Iustinus' hymn to the nymphs which, in addition to being a specific prayer, lists the several stages of his treatment. In the case of the hot springs at Ad Mediam and Germisara, the deities most worshipped there were Hercules and nymphs; it all looked a little different from the situation at Ad Aquas, where the votive offerings were dominated by the official pantheon with Jupiter as the most important god. 
Despite the many hypotheses regarding the use of the resorts before the Roman era, so far archaeologists have not been able to find any material to confirm it unambiguously; when analyzing the subject, one can only utilize sources of the Imperial period. These indicate that the years of the greatest prosperity of the spas fell between the second half of the 2nd century and the end of the reign of the Severan dynasty, a chronology apparently confirmed by small finds as well..$^{43}$ Let it suffice here to mention the treasure trove of more than six hundred coins found at Ad Mediam. While it does contain denarii minted in the declining years of the Republic, it is for the most part made up by Severan-era coins, the latest of the whole collection. ${ }^{44}$ The numismatic material from the region referred to as Germisara is only slightly later; the latest coin discovered there so far is dated to the years 244-249 CE, or the reign of Philip the Arab. ${ }^{45}$

It should also be borne in mind that the available accounts and sources do not represent all the people who visited the springs. Inscriptions, especially those on marble, were never among cheap investments, so these mostly mention state officials and veterans, that is, prefects or centurions, who could afford to erect imposing monuments. Sadly, most of those who visited the thermal waters in Dacia must remain anonymous.

\section{Abbreviations}

$\begin{array}{ll}\text { CIL } & \text { - Corpus inscriptionum latinarum } \\ \text { ILD } & \text { - Inscriptii latine din Dacia } \\ \text { IDR } & \text { - Inscriptiones Daciae Romanae I-III }\end{array}$

\section{Literature}

Benea D., Lalescu G. 1998. Contribuţii la istoria aşezării de la Ad Mediam (Băile Herculane) (Contributions at the history of the Ad Mediam Roman settlement), Sargetia 27, 267-301.

Boda I., Timoc C., Bunoiu V. 2017. Population dynamics at the spas of Roman Dacia. Case study: the population of Băile Herculane, Studia Antiqua et Archaeologica 23, 173-185.

43 Boda, Timoc, Bunoiu 2017: 181.

44 Gazdac 2012: 174

45 Pescaru, Pescaru, Bălos 2000/2001: 88.
Bozu O., Micli V. 2005. Edificii publice şi amenajări termale romane pe un plan al statiunii Băile Herculane din 1774, Banaticum 4, 123-142.

Byros G. 2011. Reconstructing Identities in Roman Dacia: Evidence from Religion, New Haven, (un unpublished doctoral dissertation in the collection of Yale University).

Dvorjetski E. 2007. Leisure, Pleasure and Healing Spa Culture and Medicine in Ancient Eastern Mediterranean, Boston.

Fodorean F. 2012. "Spa" vignettes in Tabula Peutingeriana. Travelling Ad Aquas: Thermal water resources in Roman Dacia, Ephemeris Napocensis 22, 211-222.

Fodorean F. 2019. The Peutinger Map, the Roman Army and the First Military Roads in Dacia. In Roman Roads. New evidence - new perspective, ed. A. Kolb, Berlin-Boston, 217-235.

Gazdac C. 2012. 'War and Peace'! Patterns of violence through coin hoards distribution - The Middle and Lower Danube from Trajan to Aurelianus, Istros 18, 168-198.

Gui M. 2011. Evidence for Medical and Personal Care in the Case of the Roman Army in Dacia, Ephemeris Napocensis 21, 115-130.

Nemeti S. 2001. Eine donauländische ikonographische Variante der Göttin Nantosuelta, Latomus $60,162$.

Oltean I.A. 2007. Dacia Landscape, colonisation and romanisation, London-New York.

Pescaru A. R., Pescaru E. 2001. Complexul termal roman Germisara. Faze şi etape de amenajare. In Studii de istorie antică. Omagiu profesorului Ioan Glodariu, ed. G. Florea, G. Gheorghiu, E. Iaroslavschi, Cluj-Napoca-Deva, 439-452.

Pescaru A. R., Pescaru E., Bălos A. 2000/2001. Geoagiu, com. Geoagiu, jud. Hunedoara [Germisara]. In Cronica cercetărilor arheologice din România - campania.

Piso I., Rusu A. 1990. Nymphaeum - ul de la Garmisara, Revista Monumentelor Istorice, 59, 9-17.

Piso I. 2015. Ein Gebet für die Nymphen aus Germisara, ActaMN 52, 47-68.

Rosca M., Bendea C., Vijdea A. M. 2016. Mineral and thermal waters in Romania. In Mineral and thermal waters of southeastern Europe, ed. P. Papić, New York-London, 97-114.

Szabó C. 2018. Sanctuaries in Roman Dacia Materiality and Religious Experience, Oxford. 
Varga T. 2018. Medicine, religion and society in Dacia Porolissensis, Acta Musei Napocensis 55, 63-94.
Żmudziński M. 2006. Remarks on the economic contacts of Roman Dacia. In Fontes Historiae, Studia in Honorem Demetrii Protase, ed. I. Gaiu, D. Gazdac, Cluj-Napoca, 679-682.

Adam Jakub Jarych ORCID 0000-0002-6538-9956

Nicolaus Copernicus University in Torun

Faculty of History Institute of Archaeology adamjarych@umk.pl 